Research Article

\title{
Water Treatment for Fish Aquaculture System by Biochar-Supplemented Planting Panel System
}

\author{
Sumrit Mopoung $\mathbb{D}^{1},{ }^{1}$ Vijitr Udeye, ${ }^{1}$ Supaluck Viruhpintu, ${ }^{2}$ Nonglak Yimtragool, ${ }^{2}$ \\ and Visarut Unhong ${ }^{1}$ \\ ${ }^{1}$ Department of Chemistry, Faculty of Science, Naresuan University, Phitsanulok, Thailand \\ ${ }^{2}$ Department of Biology, Faculty of Science, Naresuan University, Phitsanulok, Thailand \\ Correspondence should be addressed to Sumrit Mopoung; sumritm@nu.ac.th
}

Received 9 October 2019; Accepted 3 August 2020; Published 28 August 2020

Academic Editor: Richard A. Smith

Copyright (c) 2020 Sumrit Mopoung et al. This is an open access article distributed under the Creative Commons Attribution License, which permits unrestricted use, distribution, and reproduction in any medium, provided the original work is properly cited.

\begin{abstract}
Rice husk biochars were prepared by carbonization at $400-600^{\circ} \mathrm{C}$. The products were analyzed by FTIR, SEM-EDS, BET, and approximate analysis in order to find final products with the best properties and the lowest carbonization temperature. It has been found that the biochar prepared at $500^{\circ} \mathrm{C}$, which has $37.86 \pm 0.11 \%$ yield, $341.0776 \mathrm{~m}^{2} / \mathrm{g}$ of BET surface area, and $0.136639 \mathrm{~cm}^{3} / \mathrm{g}$ of micropore volume, is suitable for use as a root supplement in the aquaponic system. The aquaponic systems consist of aquaculture and a hydroponic system with and without biochar supplement. The control experiment consists of an aquaculture and planting panel with biochar supplement disconnected from each other. Tilapia and Chinese morning glory were used for growth studies. The water quality from all aquaculture ponds has also been analyzed at an interval of 10 days for 47 days. The results showed that the growth rates of Tilapia and Chinese morning glory in the aquaponic system with biochar were clearly higher than in the control experiment, which is in accordance with the water quality in each aquaculture pond. However, the growth rates of Tilapia ( $23.5 \mathrm{~g} /$ body vs. $22.7 \mathrm{~g} /$ body) and morning glory ( $3.907 \mathrm{~g} / \mathrm{stem}$ vs. $2.609 \mathrm{~g} / \mathrm{stem})$ in supplemented biochar system tend to be higher than the nonsupplemented biochar system. It has been shown that rice husk biochar can help in treating water in the aquaponic system by increasing the amount of dissolved oxygen in the aquaculture water and conversion of toxic compounds to those beneficial for plant growth.
\end{abstract}

\section{Introduction}

Biochar is a carbon-rich material which is produced from the pyrolysis process of biomass in a closed system using the reduction reaction [1]. Biochar materials have high adsorption for water and nutrients and are highly stable [2]. Biochar materials could increase plant growth by improving the physicochemical and biological properties of soil and retained soil fertility. Furthermore, biochar materials can also remediate organic/inorganic contaminants. Biochar has been used as hydroponic substrate for production of leafy vegetables [1]. It has also been added to sand for improved water and fertilizer retention for plant growth [2]. At present, aquaculture is utilized for fish production and has been very popular in the past decades. It has been developed to increase productivity by increasing the density of fish, which has caused problem of wastewater release to ecology systems $[3,4]$. Therefore, it is of interest to develop solutions, which will reduce wastewater problems from aquaculture systems. One solution to this problem is to connect an aquaculture system to a hydroponics system [5], in which hydroponic plants could absorb and uptake soluble compounds from the wastewater [6]. The soluble compounds have two major components. These are nitrogen and phosphorus compounds, which originate from fish feed. The nitrogen and phosphorus are retained in the body of the fish and some quantities are transferred into the culture water [4]. The combination of aquaculture (fish production) and hydroponics (plants production) is called aquaponics, which is beneficial as it reduces the use of resources (water, 
nutrients, and land) and also reduces the operation area and wastewater discharge to the environment. In addition, the products from aquaponics are organic fruits and vegetables $[7,8]$. In an aquaponic system, the aquaculture operation could be benefited by improving the quality of water, which increases stocking densities, or by reducing costs associated with treating the effluent. On the other hand, the hydroponic operation can benefit from the reduction of fertilizer inputs and labor or facilities needed to maintain adequate moisture levels [5]. However, wastewater improvement and water reuse ability in aquaponics vary depending on the hydroponic medium, hydraulic loading rate, plant species, and the plant: fish ratio [9]. One of the problems that occurs in the hydroponic part is the limited ability to remove suspended solids, which is due to the lack of culture media that can trap solids [6]. Growth media for hydroponic system could remove the suspended solids and could as well create a nutrient pool and provide adequate air space for respiration around the plant roots [10]. Cork, rice hulls, peat, coir fiber [11], Palm kernel shells, and periwinkle shells [10] have been used as growth media for hydroponic systems. These growth media are still unstable and less porous than charcoal.

Thus, this research will study the use of rice husk biochar, which is stable and can be produced using simple procedure in high quantity. The rice husk biochar was used as growth medium for hydroponic system in aquaponics. The hydroponic system with rice husk biochar was studied in comparison to hydroponic system without rice husk biochar and only with rice husk biochar for planting. The growth rates of fish and plants and the quality of water in aquaponics were studied.

\section{Materials and Methods}

2.1. Preparation and Analyzation of Biochar from Rice Husk. The rice husk was carbonized at 400,500 , and $600^{\circ} \mathrm{C}$ for $1 \mathrm{~h}$. The rice husk biochar products and rice husk were characterized by Fourier Transform Infrared Spectrometer (FTIR, Spectrum GX, Perkin Elmer, USA), Scanning Electron Microscope coupled with Energy Dispersive X-Ray Spectrometer (SEM-EDS, a LEO 1455 VP Electron Microscopy, England), and surface area and porosity analyzer using BET gas adsorption (Micromeritics TriStar II). The approximate analysis of samples was also used for their analysis. The biochar product with the best characteristics and lowest carbonization temperature was collected as growth material for planting panel system.

2.2. The Aquaponic Construction. Three aquatic ponds with width, length, and height of $2 \mathrm{~m}, 2 \mathrm{~m}$, and $70 \mathrm{~cm}$, respectively were constructed using interlocking bricks $(10 \mathrm{~cm} \times 10 \mathrm{~cm} \times 20 \mathrm{~cm}$ ) (Figure 1(a)). A plastic sheet was used to cover the bottom and sides, up to $50 \mathrm{~cm}$ depth, of the brick structure to enable water storage (volume $2 \mathrm{~m}^{3}$ ) inside each pond. Subsequently, three crop panels were also constructed with width and length of $2 \mathrm{~m}$ and $2 \mathrm{~m}$, respectively, and a $2 \%$ slope. Each panel is $30 \mathrm{~cm}$ above the aquatic pond and covered with plastic. The first crop panel
(Figure 1(b)) was filled with $15 \mathrm{~cm}$ of rice husk biochar and was not connected to an aquatic pond. This panel represents the control experiment. The first aquatic pond also acted as a control experiment. The second crop panel was covered with a net, equipped with planting sponges placed $15 \mathrm{~cm}$ apart (Figure 1(c)), and connected to the second aquatic pond. Finally, the third crop panel was filled with $15 \mathrm{~cm}$ of rice husk biochar and connected to an aquatic pond (Figure 1(d)). Morning glory (Ipomoea aquatica) was planted in each crop panel with individual plant separation of $15 \mathrm{~cm} \times 15 \mathrm{~cm}$. For aquatic system, 200 climbing perch fish (Anabas testudineus) were raised in each pond and fed twice a day (morning-evening) with $40 \%$ protein in a food mixture which amounted to $3 \%$ total weight of the fish. The water in the first and second pond was circulated with a rate flow of $200 \mathrm{~L} / \mathrm{h}$ using a pump and flowing through the second and third crop panels, respectively. The first pond was constructed in the same way as the second and third ponds but without a connection to a crop panel. The growth rates of morning glory (height and number of leaves) and climbing perch (body weight and body length) for all experiments were measured every week during the 47 days of the experiment. At the same time, the $\mathrm{pH}$ (Mettler Toledo), total solids [12], suspended solids [12], nitrite by spectrophotometer (double beam, Jusco V650) at $540 \mathrm{~nm}$, phosphorus in the orthophosphate formed by spectrophotometer at $880 \mathrm{~nm}$, and dissolved oxygen (DO) by titration with sodium thiosulphate [13] of water from all aquatic ponds were also analyzed at an interval of 10 days.

\section{Results and Discussion}

The percent yield of rice husk biochar decreased with increasing carbonization temperature from $400^{\circ} \mathrm{C}$ to $600^{\circ} \mathrm{C}$ (Table 1). However, the percent yield of biochar remained steady when the carbonization temperature was increased from $500^{\circ} \mathrm{C}$ to $600^{\circ} \mathrm{C}$. This is because the hemicellulose, cellulose, and lignin decompose at temperatures below $500^{\circ} \mathrm{C}[14]$. This is associated with the decrease of volatile matter observed upon increasing the carbonization temperature from $400^{\circ} \mathrm{C}$ to $500^{\circ} \mathrm{C}$. The volatile matter content then remains nearly constant upon the increase of carbonization temperature to $600^{\circ} \mathrm{C}$. Therefore, it can be said that the temperature needed to achieve complete carbonization of rice husk is $500^{\circ} \mathrm{C}$, which gives a yield of $37.86 \pm 0.11 \%$. The high content of fixed carbon and low content of volatile matter $(<10 \%)$ of rice husk biochar prepared using carbonization at $500^{\circ} \mathrm{C}$ indicate that the rice husk biochar is stable and suitable for use as adsorbent in the environment [14]. So, the rice husk biochar prepared at $500^{\circ} \mathrm{C}$ was collected as supplemented material for the hydroponic system.

3.1. Result of FT-IR Analysis. The FTIR transmission spectrum of rice husk (Figure 2) shows bands at $3239 \mathrm{~cm}^{-1}$, $2919 \mathrm{~cm}^{-1}, 1745 \mathrm{~cm}^{-1}$, and $1660 \mathrm{~cm}^{-1}$ corresponding to $v$ $\mathrm{O}-\mathrm{H}$ of an acid or alcohol, the aliphatic and hydroaromatic residual $\mathrm{C}-\mathrm{H}$ alkyl chains of cellulose, hemicellulose and 


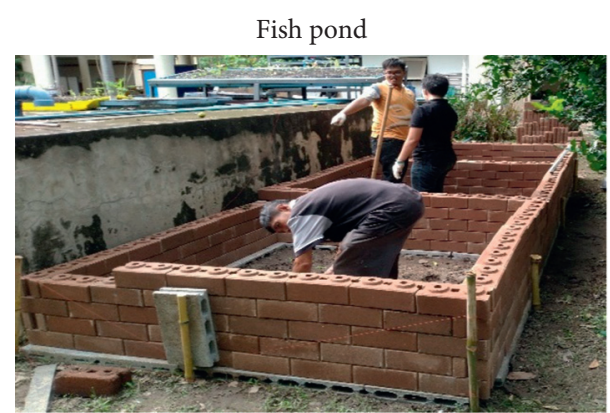

(a)

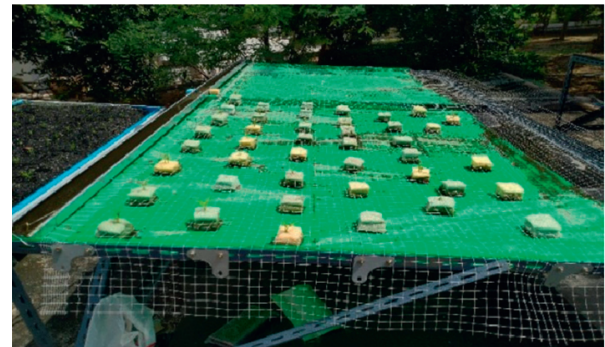

(c)

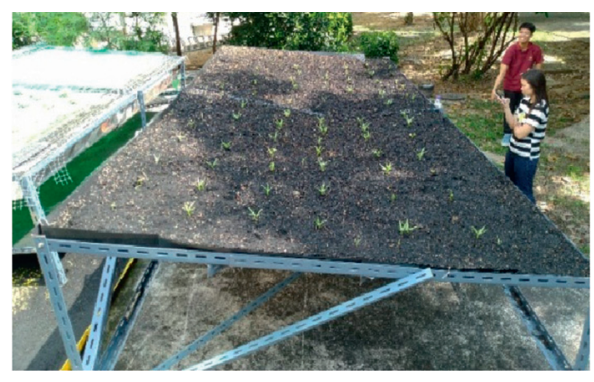

(b)

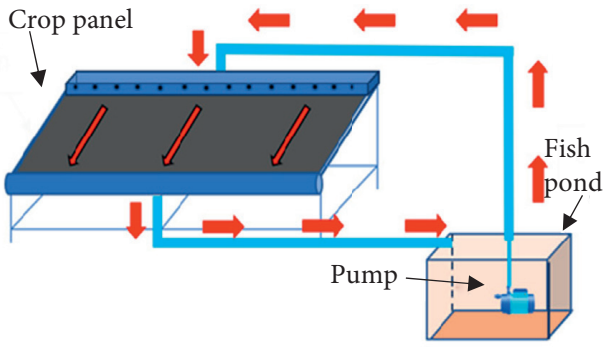

(d)

Figure 1: (a) Aquatic pond, (b) the first crop panel, (c) the second crop panel, and (d) the third crop panel.

TABle 1: Proximate analysis and \% yield of rice husk and rice husk biochar products.

\begin{tabular}{|c|c|c|c|c|c|}
\hline \multirow{2}{*}{ Sample } & \multicolumn{4}{|c|}{ Proximate analysis } & \multirow{2}{*}{$\%$ yield } \\
\hline & $\%$ moisture content & $\%$ volatile matter & $\%$ fixed carbon & $\%$ ash & \\
\hline Rice husk & $10.08 \pm 0.62$ & $69.98 \pm 2.85$ & $9.85 \pm 0.68$ & $10.08 \pm 0.27$ & - \\
\hline Rice husk biochar prepared at $400^{\circ} \mathrm{C}$ & $2.83 \pm 0.31$ & $20.13 \pm 1.32$ & $56.75 \pm 0.54$ & $20.29 \pm 0.43$ & $43.23 \pm 0.10$ \\
\hline Rice husk biochar prepared at $500^{\circ} \mathrm{C}$ & $2.81 \pm 0.57$ & $7.36 \pm 0.72$ & $68.64 \pm 2.32$ & $21.19 \pm 0.36$ & $37.86 \pm 0.11$ \\
\hline Rice husk biochar prepared at $600^{\circ} \mathrm{C}$ & $2.61 \pm 0.52$ & $5.85 \pm 0.75$ & $69.46 \pm 2.74$ & $22.08 \pm 0.31$ & $37.41 \pm 0.38$ \\
\hline
\end{tabular}

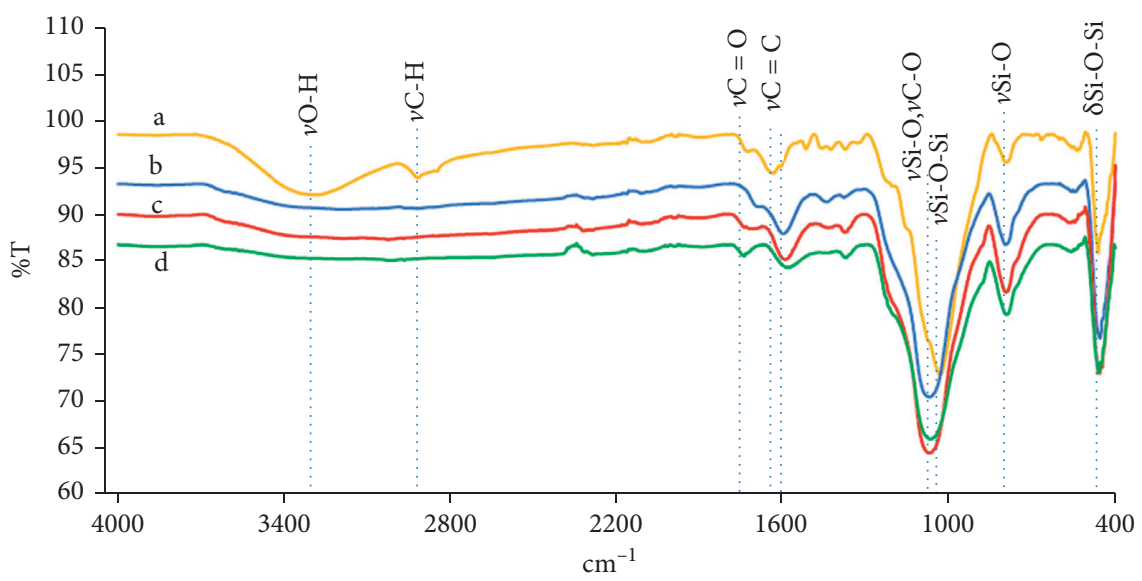

FIGURE 2: FTIR transmission spectra of (a) rice husk, (b) rice husk biochar at $400^{\circ} \mathrm{C}$, (c) rice husk biochar at $500^{\circ} \mathrm{C}$, and (d) rice husk biochar at $600^{\circ} \mathrm{C}$.

lignin, carbonyl groups in the stretching mode of aldehydes and ketones in the association of hemicelluloses with lignin, and carbonyl $(\nu-\mathrm{C}=\mathrm{O})$ of the esters in hemicellulose, and
$\mathrm{C}=\mathrm{C}$ bonds in organic components [15], respectively. The bands at $1745 \mathrm{~cm}^{-1}$ and $1660 \mathrm{~cm}^{-1}$ are also related to the elastic vibrations of the CO bond in carboxyl groups [16]. 
The spectrum also contains other bands at $1040 \mathrm{~cm}^{-1}$, $806 \mathrm{~cm}^{-1}$, and $465 \mathrm{~cm}^{-1}$, which correspond to the biogenic silica $[14,17-19]$. The band at $1040 \mathrm{~cm}^{-1}$ is associated with the asymmetric stretching vibration of $\mathrm{Si}-\mathrm{O}-\mathrm{Si}$ in the biogenic silica. This band also corresponds to $\nu \mathrm{CO}$ and $\delta \mathrm{CO}$ [16]. Finally, the bands at $806 \mathrm{~cm}^{-1}$ and $465 \mathrm{~cm}^{-1}$ correspond to the symmetric vibrations of the $\mathrm{Si}-\mathrm{O}$ bonds in the silicon-oxygen tetrahedrons $\left(\mathrm{SiO}_{4}\right)$ and $\mathrm{Si}-\mathrm{O}$-Si bending vibrations [15]. After the carbonization process at $400-600^{\circ} \mathrm{C}$, the FTIR bands of the rice husk biochar obtained at $400^{\circ} \mathrm{C}$ (Figure 2) show a band at $1090 \mathrm{~cm}^{-1}$, which shifted from $1040 \mathrm{~cm}^{-1}$ and corresponds to the biogenic silica. It is a characteristic of the tridymite, which is due to the $v \mathrm{Si}-\mathrm{O}$. The peaks at $804 \mathrm{~cm}^{-1}$ and $465 \mathrm{~cm}^{-1}$ related to the ring structure of the $\mathrm{SiO}_{4}$ tetrahedra of silica belonging to the cristobalite type and $\delta \mathrm{Si}-\mathrm{O}-\mathrm{Si}$, respectively [16]. Furthermore, it was observed that the bands of $\nu \mathrm{O}-\mathrm{H}, \nu \mathrm{C}$ $\mathrm{H}$, and $\nu \mathrm{C}=\mathrm{O}$ of hemicellulose, cellulose, and lignin disappeared, while the bands of $\nu \mathrm{C}=\mathrm{O}\left(1710 \mathrm{~cm}^{-1}\right)$ and $\nu \mathrm{C}=\mathrm{C}$ $\left(1615 \mathrm{~cm}^{-1}\right)$ began to appear. This shows that organic substances have decomposed and that aromatic carbon structures begin to develop at $400^{\circ} \mathrm{C}$. Reactions leading to the development of aromatic structures during carbonization are dehydration, demethylation, demethoxylation, decarbonylation, and decarboxylation of hydroxyl groups and other oxygen-containing functional groups. The results of these reactions cause the development of $\mathrm{C}=\mathrm{C}$ bonds and smaller aromatic rings [14], which is confirmed by the increased intensity of the band at $1615 \mathrm{~cm}-1$. Similarly, the rice husk biochars prepared at $500-600^{\circ} \mathrm{C}$ (Figure 2) show more characteristics of biochar and silica with dominant $\nu \mathrm{C}=\mathrm{O}, \nu \mathrm{C}=\mathrm{C}, \nu \mathrm{Si}-\mathrm{O}$, and $\delta \mathrm{Si}-\mathrm{O}-\mathrm{Si}$ bands. The bands of $\nu \mathrm{C}=\mathrm{O}, \nu \mathrm{C}=\mathrm{C}$, especially, become more separated changing their positions from $1618 \mathrm{~cm}^{-1}$ to $1708 \mathrm{~cm}^{-1}$ and $1615 \mathrm{~cm}^{-1}$ to $1755 \mathrm{~cm}^{-1}$. This indicates the formation of more stable condensed carbon structures.

3.2. Result of SEM-EDS Analysis. Figure 3 shows SEM images of rice husk biochar prepared by carbonization at temperatures between $400^{\circ} \mathrm{C}$ and $600^{\circ} \mathrm{C}$. The image showed that rice husk biochar prepared at $400^{\circ} \mathrm{C}$ (Figure $3(\mathrm{a})$ ) has smooth embossed surface with some small particles. However, increasing the carbonization temperature to $500^{\circ} \mathrm{C}$ and $600^{\circ} \mathrm{C}$ results in the formation of hollow tunnels with open pores. The presence of small particles on the walls of the tunnels of the biochar can be observed. These results are related to the degradation of volatile matter, for example, cellulose, hemicellulose, and lignin. For example, hemicellulose decomposes between $220^{\circ} \mathrm{C}$ and $350^{\circ} \mathrm{C}$, cellulose decomposes between $315^{\circ} \mathrm{C}$ and $400^{\circ} \mathrm{C}$, and lignin decomposes above $400^{\circ} \mathrm{C}$ [14]. It has been reported that the completion of charcoal formation is due to the complete pyrolysis of lignin [16]. Therefore, the open pores are observed in rice husk biochars prepared at temperatures above $400^{\circ} \mathrm{C}$ but did not appear on the surface of rice husk biochar prepared at $400^{\circ} \mathrm{C}$. These results correspond to the results of FTIR in which the functional groups belonging to cellulose, hemicellulose, and lignin of biochar disappear for materials prepared at $500^{\circ} \mathrm{C}$ and $600^{\circ} \mathrm{C}$. As can be seen from the results of EDS (Table 2), the carbon content of rice husk biochar materials prepared at $500-600^{\circ} \mathrm{C}$ is constant with low oxygen content. This confirms that the degree of carbonization of rice husk is completed at about $500^{\circ} \mathrm{C}$. In addition, the amount of Si of biochar is quite high which is consistent with the results of FTIR.

\subsection{Surface Area and Porosity Analysis of Rice Husk Biochar.} Data on surface area and porosity of rice husk biochar are shown in Table 3. It can be seen that the surface area and pore volume of biochar prepared at $400^{\circ} \mathrm{C}$ are very low. This confirms that the carbonization of rice husk at $400^{\circ} \mathrm{C}$ results in incomplete biochar production which corresponds to the results of the above analyses especially images from SEM (Figure 3(a)). For biochars prepared by carbonization of rice husk at $500-600^{\circ} \mathrm{C}$, the surface area and pore volume (micropore and mesopore) are drastically increased. The content of mesopores, especially, increases upon increasing the carbonization temperature from $500^{\circ} \mathrm{C}$ to $600^{\circ} \mathrm{C}$. This is caused by complete degradation of volatile matter above $400^{\circ} \mathrm{C}$. Furthermore, the surface area and volume of mesopores are highly increased between $500^{\circ} \mathrm{C}$ and $600^{\circ} \mathrm{C}$. This is the result of secondary decomposition of the biochar components together with the collapse of the microporous structures, which consequently pave the way for the formation of the mesoporous structure when the pyrolysis temperature is increased [14]. However, surface area and pore volume of rice husk biochars prepared at $500-600^{\circ} \mathrm{C}$ are still low. This may be caused by the fact that the pores of the biochar contain fine particles and ash as shown in the SEM image (Figures 3(b) and 3(c)).

3.4. Water Analysis. Table 4 shows the data of water analysis resulting from aquatic ponds numbers $1-3$ on $7^{\text {th }}-47^{\text {th }}$ days. This shows that the supplementation of biochar in the plant panel connected to the aquatic pond (number 3 ) could reduce the total solid, suspended solid, nitrite, and orthophosphate content in water samples as compared to the aquatic pond (number 1) and aquatic pond connect to hydroponic system without rice husk biochar (number 2) while it could increase the dissolved oxygen (DO) content in the water samples. This is because the suspended solids, which were the cause of water turbidity [8], were filtered by biochar and plant roots while dissolved solid, nitrite, and orthophosphate were adsorbed by the rice husk biochar and absorbed by plant root for growth. However, this content is more reduced after $17^{\text {th }}$ day. This is attributed to filtering and absorption by root of the Chinese morning glory after full growth. The suspended solid was more extensively filtered as there are more roots, which have spread all over the biochar, while some of the dissolved solids, nitrite, and orthophosphate were used for the growth of the root, stem, and leaf of Chinese morning glory as well as bacteria [20]. This phenomenon has occurred in the aquatic pond connected to the hydroponic system without rice husk biochar (number 2) as well. It can be seen that the nitrite content in water of the aquatic pond connect to plant panel with rice husk biochar 


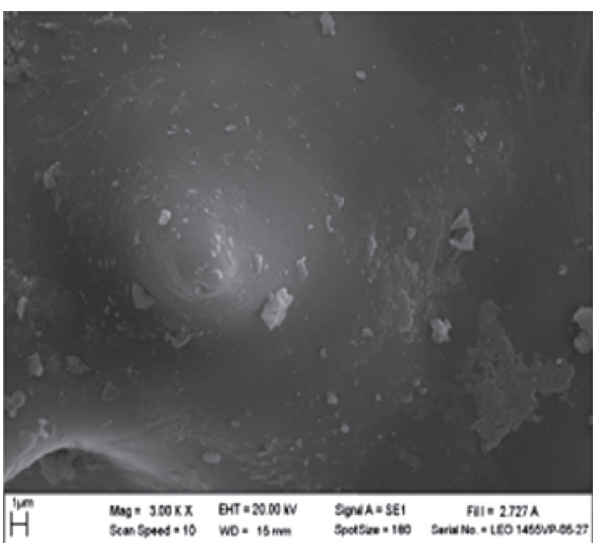

(a)

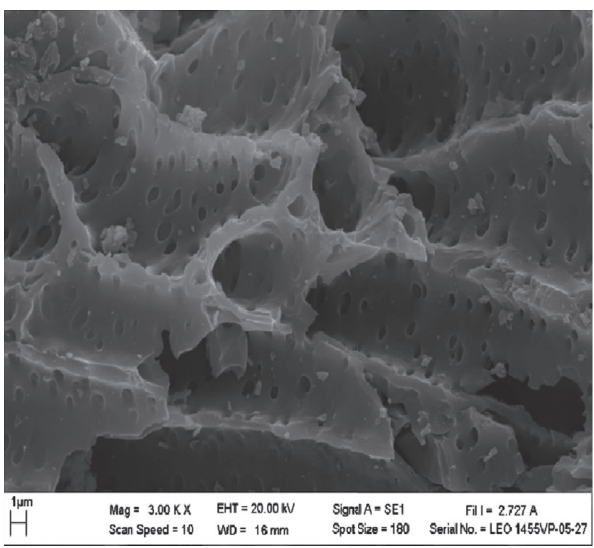

(c)

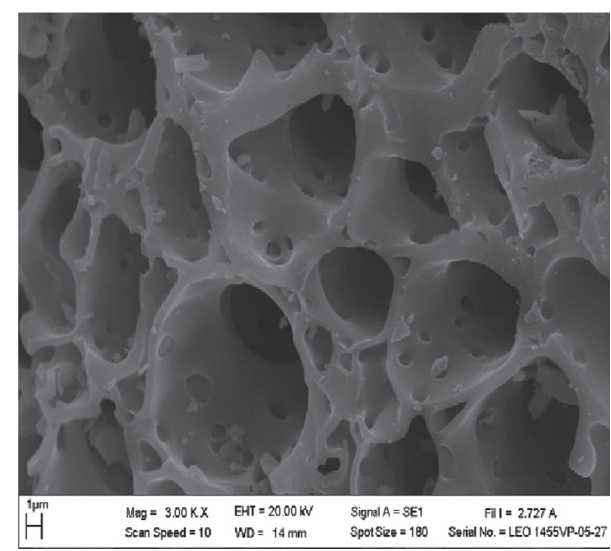

(b)

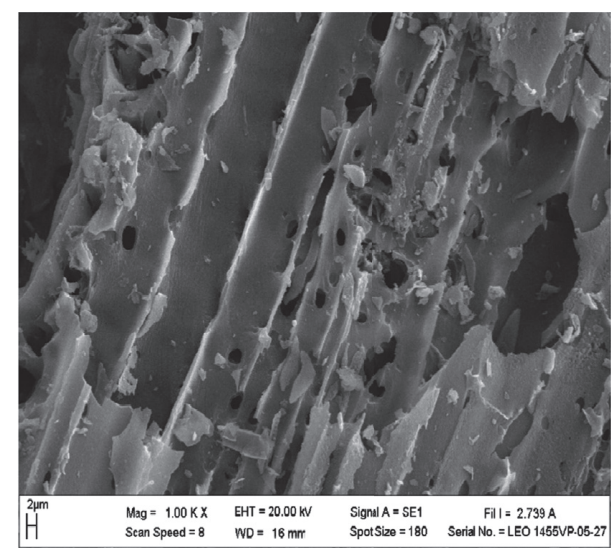

(d)

FiguRE 3: SEM images of (a) rice husk biochar prepared at $400^{\circ} \mathrm{C}$, (b) rice husk biochar prepared at $500^{\circ} \mathrm{C}$, (c) rice husk biochar prepared at $600^{\circ} \mathrm{C}$, and (d) rice husk biochar prepared at $500^{\circ} \mathrm{C}$ after being used as supplemented plant root for 47 days.

TABLE 2: Elemental composition of rice husk biochar from EDS.

\begin{tabular}{lccccc}
\hline \multirow{2}{*}{ Samples of biochar prepared at } & \multicolumn{4}{c}{ Elements composition (\%wt) } \\
& $\mathrm{C}$ & $\mathrm{O}$ & $\mathrm{Si}$ & $\mathrm{K}$ & $\mathrm{P}$ \\
\hline $400^{\circ} \mathrm{C}$ & 74.62 & 22.02 & 2.94 & 0.42 & - \\
$500^{\circ} \mathrm{C}$ & 77.44 & 16.54 & 5.39 & 0.63 & - \\
$600^{\circ} \mathrm{C}$ & 78.41 & 13.71 & 6.95 & 0.92 & - \\
After use & 62.20 & 18.90 & 16.92 & - & - \\
\hline
\end{tabular}

TABLE 3: Surface area and porosity of rice husk biochar by BET.

\begin{tabular}{|c|c|c|c|c|}
\hline Samples of biochar prepared at & $\begin{array}{c}\text { BET surface area } \\
\left(\mathrm{m}^{2} / \mathrm{g}\right)\end{array}$ & $\begin{array}{l}\text { Micropore volume } \\
\left(\mathrm{cm}^{3} / \mathrm{g}\right)\end{array}$ & $\begin{array}{c}\text { Surface area of pores between } 17 \\
\AA \text { and } 3,000 \AA\left(\mathrm{m}^{2} / \mathrm{g}\right)\end{array}$ & $\begin{array}{c}\text { volume of pores between } 17 \AA \\
\text { and } 3,000 \AA\left(\mathrm{cm}^{3} / \mathrm{g}\right)\end{array}$ \\
\hline $400^{\circ} \mathrm{C}$ & 7.6311 & 0.000278 & 2.2491 & 0.006805 \\
\hline $500^{\circ} \mathrm{C}$ & 341.0776 & 0.136639 & 23.0061 & 0.024664 \\
\hline $600^{\circ} \mathrm{C}$ & 414.5242 & 0.149359 & 31.7760 & 0.025080 \\
\hline
\end{tabular}

has a value not exceeding the specified $(2.0 \mathrm{mg} / \mathrm{L})$ for fish pond water [20]. This shows that supplementing biochar has an important role in the elimination of these substances in aquatic pond. However, the hydroponic system without biochar can also reduce the nitrite amount below $2.0 \mathrm{mg} / \mathrm{L}$ for a substantial amount of time. This is because, during the long planting time, the Chinese morning glory root becomes enlarged, which can increase the surface area for absorption of nitrite (in nitrate form that is converted from nitrite by nitrification). The content of orthophosphate has increased 
TABLE 4: Total solids, suspended solids, nitrite, orthophosphate, dissolved oxygen, and $\mathrm{pH}$ of water in aquatic ponds and hydroponic system.

\begin{tabular}{|c|c|c|c|c|c|c|}
\hline Pond number & Total solids $(\mathrm{mg} / \mathrm{L})$ & Suspended solids $(\mathrm{mg} / \mathrm{L})$ & Nitrite $(\mathrm{mg} / \mathrm{L})$ & Orthophosphate (mg/L) & Dissolved oxygen $(\mathrm{mg} / \mathrm{L})$ & $\mathrm{pH}$ \\
\hline \multicolumn{7}{|c|}{$7^{\text {th }}$ day } \\
\hline 1 & 162 & 94 & 1.2083 & 0.2347 & 5.34 & 6.542 \\
\hline 2 & 150 & 80 & 0.9439 & 0.2234 & 6.35 & 6.568 \\
\hline 3 & 132 & 54 & 0.1613 & 0.1435 & 6.41 & 6.983 \\
\hline \multicolumn{7}{|l|}{$17^{\text {th }}$ day } \\
\hline 1 & 204 & 172 & 2.1611 & 0.3253 & 5.73 & 6.573 \\
\hline 2 & 83 & 96 & 1.1123 & 0.2023 & 6.65 & 6.751 \\
\hline 3 & 56 & 43 & 0.1216 & 0.1364 & 7.34 & 7.163 \\
\hline \multicolumn{7}{|l|}{$27^{\text {th }}$ day } \\
\hline 1 & 290 & 228 & 3.6583 & 0.3425 & 5.54 & 6.625 \\
\hline 2 & 72 & 64 & 2.8732 & 0.1958 & 6.52 & 6.356 \\
\hline 3 & 42 & 34 & 0.1486 & 0.1743 & 7.31 & 6.923 \\
\hline \multicolumn{7}{|l|}{$37^{\text {th }}$ day } \\
\hline 1 & 328 & 280 & 3.0708 & 0.4173 & 5.38 & 6.831 \\
\hline 2 & 60 & 47 & 1.6521 & 0.2042 & 6.75 & 6.259 \\
\hline 3 & 36 & 25 & 0.1209 & 0.1725 & 6.40 & 7.038 \\
\hline \multicolumn{7}{|l|}{$47^{\text {th }}$ day } \\
\hline 1 & 373 & 302 & 3.1937 & 0.4264 & 5.30 & 6.878 \\
\hline 2 & 43 & 32 & 1.6190 & 0.2273 & 6.78 & 7.078 \\
\hline 3 & 35 & 28 & 0.1641 & 0.1755 & 7.40 & 7.048 \\
\hline
\end{tabular}

Pond number $1=$ aquatic pond, pond number $2=$ aquatic pond connect to hydroponic system without rice husk biochar, and pond number $3=$ aquatic pond connect to planting panel with rice husk biochar.

steadily with experimental duration for all aquaponic ponds. This is because plants use high amount of phosphate for root growth at the early stage of development [20]. The dissolved oxygen value exhibits an increasing trend from pond 1 to pond 3. There were water circulating systems, which can increase contact of water and atmosphere air, installed in all ponds. The addition of biochar in the plant bed system, especially, can increase the contact surface area between water and air. This is caused by high porosity and surface area of the biochar that can be a channel for air and create contact surfaces. In all cases, the DO levels are higher than the lowest levels $(5 \mathrm{mg} / \mathrm{L})$ required for warm water fish farming [8]. However, the low DO in aquatic pond number 1 is due to a higher microorganism activity and higher decomposition of soluble solids, which use high amounts of oxygen [21]. Finally, the $\mathrm{pH}$ values of the aquatic waters in all ponds are in the very weakly acidic to neutral range. The value increases slightly from pond 1 to pond 3 . It shows that acidic substances made by fish farming $\left(\mathrm{CO}_{2}\right.$ from fish breathing) have been eliminated by absorption in the plants and the adsorption on the biochar. However, the $\mathrm{pH}$ values of the water from all fish ponds are still within the limited range (6.5-9.0) which is an optimum condition for the conversion of ammonia to nitrite by bacteria. It is also in the normal range for the hydroponic system, which is generally between 5 and 7.5 [20].

\section{Growth of Plant and Fish}

4.1. Growth of Plant. Table 5 shows data for the growth of the Chinese morning glory after planting for 47 days (normally, it takes only 21 days to grow until harvesting). It can be seen that all of the growth parameters of the Chinese morning glory for crop panel number 3 (supplemented with rice husk biochar and connected to aquatic pond) are higher than crop panel number 1 (plant bed supplemented with rice husk biochar and disconnect from aquatic pond) and crop panel number 2 (without biochar and connected to aquatic pond). The growth of the Chinese morning glory in crop panel number 1 is low. This is because crop panel number 1 , which is a control experiment, was not supplemented with a fertilizer and did not have water from the circulating aquatic system. However, the growth parameters of both crop panels numbers 2 and 3 are almost equal. This shows that the Chinese morning glory of both crop panels received roughly equal number of nutrients for growth from the circulating water. It has been shown that high plant growth results in a large number of substances in the water being used. Long plant roots, especially, which have a high surface area could absorb nutrients with high efficiency. As reported by Estim et al. [20], plants with larger root surface area provide greater surface area for attachment of microbial organisms that convert ammonia to nitrite and nitrite to nitrate. In addition, high concentration of DO is one of the factors that could be leading to increased mass of the plants. It can be seen that the amount of nitrite in the aquatic ponds 2 and 3 is low in comparison to aquatic pond 1, while the DO is high. Moreover, using rice husk biochar as a root supplement increased the efficiency of water treatment and nutrient absorption of plant roots by providing surface area for attachment of bacteria. Furthermore, considering the plant root growth, it can be seen that the plant roots in aquatic pond 2 exhibit higher growth than the plant roots in aquatic pond 3. This may be due to the use of sponge as a root supplement for plant panel 2, which is not distributed completely throughout planting panels, causing limited 
TABLE 5: The results of the growth measurement of the morning glory after 47 days.

\begin{tabular}{lccccccc}
\hline $\begin{array}{l}\text { Crop panel } \\
\text { number }\end{array}$ & $\begin{array}{c}\text { Stem height } \\
(\mathrm{cm})\end{array}$ & $\begin{array}{c}\text { Number of } \\
\text { leaves }(\text { stem })\end{array}$ & $\begin{array}{c}\text { Fresh stem } \\
\text { weight }(\mathrm{g} / \mathrm{stem})\end{array}$ & $\begin{array}{c}\text { Fresh root } \\
\text { weight }(\mathrm{g} / \mathrm{stem})\end{array}$ & $\begin{array}{c}\text { Dried stem } \\
\text { weight }(\mathrm{g} / \mathrm{stem})\end{array}$ & $\begin{array}{c}\text { Dried root } \\
\text { weight }(\mathrm{g} / \mathrm{stem})\end{array}$ & $\begin{array}{c}\text { Trunk } \\
\text { diameter }(\mathrm{cm})\end{array}$ \\
\hline 1 & 16.34 & 6.6 & 1.000 & 0.542 & 0.1402 & 0.0560 & 0.25 \\
2 & 23.65 & 8.9 & 2.609 & 1.899 & 0.3710 & 0.1390 & 0.48 \\
3 & 23.77 & 9.7 & 3.907 & 1.418 & 0.3872 & 0.1130 \\
\hline
\end{tabular}

amount of water around the roots. On the other hand, the plant panel connected to aquatic pond 3 used rice husk biochar to spread water evenly in the full area of the plant panel. In this panel, water and nutrient absorption proceed efficiently, which facilitates the beneficial bacterial activity [20]. Therefore, the plant roots in the plant panel 2 were more dispersed than in the plant panel 3 . The growth of the stems and leaves in the planting panels 2 and 3 is high due to the high growth of plant fine roots [22].

4.2. Growth of Fish. Figure 4 shows the graph of fish growth over the 47 days. The graph shows that the growth of fish in pond number 1 (Figure 4 ) is slower than in ponds numbers 2 and 3 (Figure 4) throughout the trial period. This difference between pond 1 and ponds 2 and 3 becomes more evident with increasing farming time. The growth of fish in ponds numbers 2 and 3 are slightly different and tend to come closer together with extended periods of time. This is because of the good quality of water in aquatic culture pond numbers 2 and 3 , which is caused by plants absorbing compounds that are toxic to fish from aquatic water. This can be seen from the good growth of the plants. Therefore, the resulting water quality is better for the fish growth in aquatic ponds 2 and 3 in comparison to aquatic pond 1 . For aquatic pond 1 , water is not passed through the planting panel and therefore substances which can be toxic to fish are not being eliminated in this case. These effects cause the fish to have higher stress. For aquatic ponds 2 and 3, fish in both aquatic ponds grow with similar rate, especially at longer time points. This is because the plant roots have spread more extensively in the planting panel 2 at later times. However, the growth of fish in aquatic pond 3 is still likely better than aquatic pond 2 . This shows that rice husk biochar has effect on water treatment as it provides surface area for attachment of bacteria that help in conversion of toxic chemicals into nontoxic substances, improving water quality and absorption of nutrients through the plant roots [20].

\subsection{SEM and EDS of Biochar after Being Used for Water} Treatment. Figure 3(d) and Table 2 show the SEM image and elemental composition of rice husk biochar prepared at $500^{\circ} \mathrm{C}$ after its use as supplemental plant root material for 47 days. The results indicate that some mass of biochar has been destroyed, which may be caused by insertion of the plant fibrous roots and swelling with water. As a result, decreased amount of $\mathrm{C}$ and increased amount of $\mathrm{Si}$ are observed. In addition, the amount of $\mathrm{O}$ is also increased in the used material, which may be related to the increase in $\mathrm{DO}$ values in aquatic water and oxidation of plant roots. The contents of

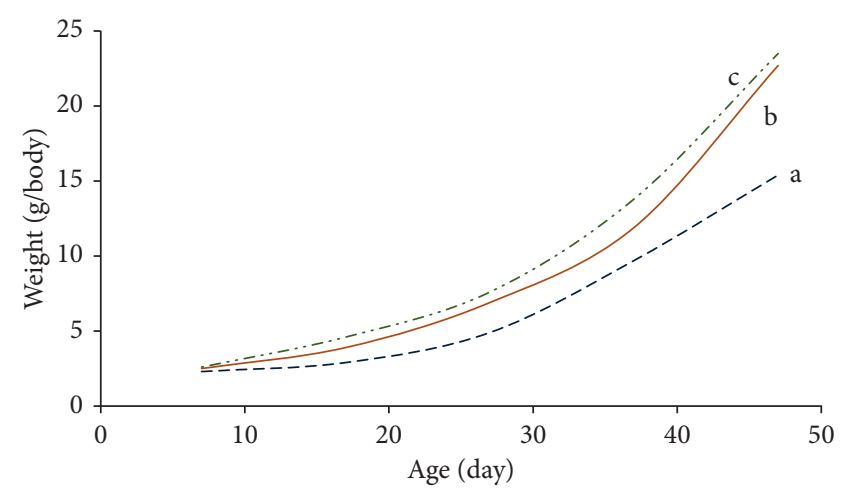

FIGURE 4: Graph showing the growth of fish by the time in (a) pond number 1 , (b) pond number 2 , and (c) pond number 3 .

$\mathrm{P}$ and $\mathrm{Ca}$ are derived from the feed digestion by fish, which may get accumulated on the biochar.

\section{Conclusion}

Investigation of the preparation of biochar at carbonization temperatures in the range $400-600^{\circ} \mathrm{C}$ found that the biochar prepared at $500^{\circ} \mathrm{C}$ had stable and porous properties making it suitable to act as root supplement in the planting system. The biochar material was prepared with the yield of $37.86 \pm 0.11 \%$. Using this biochar as a root supplement in the aquaponic system indicated that the growth of Tilapia and Chinese morning glory was increased in its presence in comparison to experiments without the inclusion of the biochar. Clear differences are observed especially with the control systems of isolated aquaculture and planting panel, where the growth of both Tilapia and morning glory was clearly retarded. Rice husk biochar has improved the water quality in the aquaculture system by helping to maintain the DO level above the specified limit of $6.40-7.40 \mathrm{mg} / \mathrm{L}$ while the nitrite content remained below the toxicity level of $0.1216-0.1641 \mathrm{mg} / \mathrm{L}$. The biochar, also a tendency, reduces the number of total solids and suspended solids in the water. The biochar can act as a filter and adsorbent due to its porosity and high surface area. Rice husk biochar also helped plant roots get more nutrients for root and stem growth as the biochar is able to store nutrients well. In this regard, as the time frame for fish farming and plant growth in the aquaponic system increases, the efficiency of water treatment in the system is improved as the roots of plants grow and spread out more.

\section{Data Availability}

The data used to support the findings of this study are included within the article. 


\section{Conflicts of Interest}

The authors declare that there are no conflicts of interest regarding the publication of this paper.

\section{Authors' Contributions}

Sumrit Mopoung designed the research plan, organized the study, and wrote all paragraphs. Vijitr Udeye and Visarut Unhong are coresearchers who have reported and analyzed the data presented in this paper. Supaluck Viruhpintu and Nonglak Yimtragool are coresearchers who have supervised animal operations for scientific purposes in studying the growth of Tilapia.

\section{Acknowledgments}

The authors acknowledge Science Lab Center, Faculty of Science, Naresuan University, for all of the analysis. This research was under the supervision of the Committee on Animal Execution for Science, Naresuan University (project no. NU-AQ610718 and certification no. 616100 007). The National Research Council of Thailand and Naresuan University are financial supporters under project code R2562B062.

\section{References}

[1] Y. M. Awad, S.-E. Lee, M. B. M. Ahmed et al., "Biochar, a potential hydroponic growth substrate, enhances the nutritional status and growth of leafy vegetables," Journal of Cleaner Production, vol. 156, pp. 581-588, 2017.

[2] S. F. Vaughn, F. Dan Dinelli, B. Tisserat, N. Joshee, M. M. Vaughan, and S. C. Peterson, "Creeping bentgrass growth in sand-based root zones with or without biochar," Scientia Horticulturae, vol. 197, pp. 592-596, 2015.

[3] B. W. Brooks and J. L. Conkle, "Commentary: perspectives on aquaculture, urbanization and water quality," Comparative Biochemistry and Physiology Part C: Toxicology \& Pharmacology, vol. 217, pp. 1-4, 2019.

[4] A. B. Dauda, A. Ajadi, A. S. Tola-Fabunmi, and A. O. Akinwole, "Waste production in aquaculture: sources, components and managements in different culture systems," Aquaculture and Fisheries, vol. 4, no. 3, pp. 81-88, 2019.

[5] K. M. Buzby, N. L. Waterland, K. J. Semmens, and L.-S. Lin, "Evaluating aquaponic crops in a freshwater flow-through fish culture system," Aquaculture, vol. 460, pp. 15-24, 2016.

[6] J. Pan, H. Sun, A. Nduwimana et al., "Hydroponic plate/ fabric/grass system for treatment of aquacultural wastewater," Aquacultural Engineering, vol. 37, no. 3, pp. 266-273, 2007.

[7] S. Wongkiew, Z. Hu, K. Chandran, J. W. Lee, and S. K. Khanal, "Nitrogen transformations in aquaponic systems: a review," Aquacultural Engineering, vol. 76, pp. 9-19, 2017.

[8] L. Pérez-Urrestarazu, J. Lobillo-Eguíbar, R. Fernández-Cañero, and V. M. Fernández-Cabanás, "Suitability and optimization of FAO's small-scale aquaponics systems for joint production of lettuce (Lactuca sativa) and fish (Carassius auratus)," Aquacultural Engineering, vol. 85, pp. 129-137, 2019.

[9] K. K. T. Nuwansi, A. K. Verma, G. Rathore, C. Prakash, M. H. Chandrakant, and G. P. W. A. Prabhath, "Utilization of phytoremediated aquaculture wastewater for production of koi carp (Cyprinus carpio var. koi) and gotukola (Centella asiatica) in an aquaponics," Aquaculture, vol. 507, pp. 361-369, 2019.

[10] A. S. Oladimeji, S. O. Olufeagba, V. O. Ayuba, S. G. Sololmon, and V. T. Okomoda, "Effects of different growth media on water quality and plant yield in a catfish-pumpkin aquaponics system," Journal of King Saud University-Science, vol. 32, no. 1, pp. 60-66, 2020, In press.

[11] F. Martínez, S. Castillo, C. Borrero, S. Pérez, P. Palencia, and M. Avilés, "Effect of different soilless growing systems on the biological properties of growth media in strawberry," Scientia Horticulturae, vol. 150, pp. 59-64, 2013.

[12] APHA, 2005 APHA Standards Methods for the Examination of Water and Wastewater, American Public Health Association, Washington DC, USA, 21st edition, 2005.

[13] J. H. Carpenter, "The Chesapeake bay institute technique for the Winkler dissolved oxygen method," Limnology and Oceanography, vol. 10, no. 1, pp. 141-143, 1965.

[14] Q. Abbas, G. Liu, B. Yousaf et al., "Contrasting effects of operating conditions and biomass particle size on bulk characteristics and surface chemistry of rice husk derivedbiochars," Journal of Analytical and Applied Pyrolysis, vol. 134, pp. 281-292, 2018.

[15] M. C. F. De Cordoba, J. Matos, R. Montaña et al., "Sunlight photoactivity of rice husks-derived biogenic silica," Catalysis Today, vol. 328, pp. 125-135, 2019.

[16] I. Uzunov, S. Uzunova, D. Angelova, and A. Gigova, "Effects of the pyrolysis process on the oil sorption capacity of rice husk," Journal of Analytical and Applied Pyrolysis, vol. 98, pp. 166-176, 2012.

[17] S. Azat, A. V. Korobeinyk, K. Moustakas, and V. J. Inglezakis, "Sustainable production of pure silica from rice husk waste in Kazakhstan," Journal of Cleaner Production, vol. 217, pp. 352-359, 2019.

[18] N. Wen, Y. Zhao, Z. Yu, and M. Liu, "A sludge and modified rice husk ash-based geopolymer: synthesis and characterization analysis," Journal of Cleaner Production, vol. 226, pp. 805-814, 2019.

[19] Z. Ullah, Z. Man, A. S. Khan et al., "Extraction of valuable chemicals from sustainable rice husk waste using ultrasonic assisted ionic liquids technology," Journal of Cleaner Production, vol. 220, pp. 620-629, 2019.

[20] A. Estim, S. Saufie, and S. Mustafa, "Water quality remediation using aquaponics sub-systems as biological and mechanical filters in aquaculture," Journal of Water Process Engineering, vol. 30, Article ID 100566, 2019.

[21] J. Suhl, D. Dannehl, W. Kloas et al., "Advanced aquaponics: evaluation of intensive tomato production in aquaponics vs. conventional hydroponics," Agricultural Water Management, vol. 178, pp. 335-344, 2016.

[22] T. Yang and H. J. Kim, "Nutrient management regime affects water quality, crop growth, and nitrogen use efficiency of aquaponic systems," Scientia Horticulturae, vol. 256, Article ID 108619, 2019. 